\title{
Editorial
}

Leonir Lorenzetti leonirlorenzetti22@gmail.com orcid.org/0000-0001-8327-9147 (UFPR), Curitiba, Paraná, Brasil

\section{A Alfabetização Científica na Educação em Ciências}

A alfabetização científica (AC) pode ser considerada como um dos eixos emergentes na pesquisa em Educação em Ciências no Brasil, sendo apontada como a meta da aprendizagem e o objetivo do ensino, na medida em que almeja ampliar o conhecimento sobre ciência e tecnologia, atrelados à uma formação para a cidadania.

A temática, segundo Bybbe (1995), surge nos Estados Unidos da América nos anos sessenta do século passado ao enfatizar as metas relacionadas aos aspectos sociais da Ciência, visando: (a) avaliar o desenvolvimento histórico e social da ciência; (b) conhecer as características da ciência moderna; (c) entender e valorizar a relação social e cultural da ciência; e (d) reconhecer a responsabilidade social da ciência.

As discussões sobre a natureza da ciência, conceitos da ciência, processos de ciência, valores de ciência, ciência e sociedade, interesses em ciência e habilidades associadas com ciência foram os grandes temas enfocados nos anos setenta, procurando responder a questão do que é - unificado na educação em ciência.

Nos anos oitenta, os temas envolveram a "Ciência, Tecnologia e Sociedade: Educação Científica para os anos oitenta". Destacaram-se as discussões sobre (a) processos científicos e tecnológicos e as habilidades de investigação; (b) conhecimento científico e tecnológico; (c) habilidades e conhecimentos de ciência e tecnologia em decisões pessoais e sociais; (d) atitudes, valores e avaliação de ciência e tecnologia; e (e) as interações entre Ciência, Tecnologia e Sociedade por contextos de assuntos sociais relacionados à ciência. Assim, podemos inferir que uma das formas mais eficientes e promissoras de promover a alfabetização científica é através dos Estudos de Ciência, Tecnologia e Sociedade, tanto nos espaços escolarizados como nos espaços não formais.

No Brasil, as discussões emergem na década de 1990. Especificamente no Encontro Nacional de Pesquisa em Educação em Ciência (ENPEC) as menções à AC aparecem na primeira edição, em 1997, nos trabalhos de Leal e Souza (1997) e Leal e Selles (1997), mas, não se constituem na temática central dos trabalhos. As autoras fazem pequenas inferências à AC, destacando conceitos, finalidades e que sua promoção ocorre em contextos diversos, como escolas, museus, revista, entre outros.

O estudo realizado por Viecheneski, Lorenzetti e Carletto (2015) mostra que no período de 1997 a 2009, em sete edições, foram apresentados somente 24 trabalhos. Analisando as Atas do ENPEC no período de 2011 a 2017, utilizando a expressão "alfabetização científica", no título ou palavras-chave, identificamos a existência de 131 trabalhos, sendo que a produção se mantêm constante neste período, ou seja: 29 trabalhos em 2011; 32 trabalhos em 2013 e também em 2015 
e 38 trabalhos em 2017. Assim, chegamos ao total de 155 trabalhos que discutem a alfabetização científica na Educação em Ciências, disseminada no maior evento de Educação em Ciências do Brasil.

Estes trabalhos estão concentrados principalmente na área "Alfabetização científica e tecnológica, abordagens CTS e CTSA e educação em ciências", mas também são discutidos nas áreas de "Educação em espaços não formais e divulgação científica", "Ensino e aprendizagem de conceitos científicos" "Linguagens, discurso e educação em ciências", "Formação de professores de ciências", entre outros.

Consultando o Banco de Teses da CAPES foi possível identificar que nos Programas de Pós-Graduação o primeiro trabalho sobre AC foi produzido por Cazelli (1992) discutindo a alfabetização científica e os museus interativos de ciência, voltado para a educação não formal. Já em relação à educação formal o trabalho de Lorenzetti (2000) pode ser considerado pioneiro, uma vez que apresenta os fundamentos teóricos e metodológicos para a promoção da alfabetização científica no contexto escolar. A partir dos anos 2000 há uma produção constante de dissertação e teses produzidas e que ampliam as discussões sobre a temática, ganhando impulso com a pesquisa de Sasseron (2008) ao propor os indicadores de alfabetização científica.

Ao olhar para a produção brasileira é possível identificar que no período de 2000 a 2008 os trabalhos priorizam a discussão sobre os fundamentos teóricos da alfabetização científica e as formas de sua promoção na Educação em Ciências, tendo como foco as ações docentes, com ênfase no processo de ensino. Com a publicação dos indicadores de alfabetização científica por Sasseron (2008), as pesquisas passam a enfatizar a aprendizagem dos estudantes, procurando identificar nas interações discursivas como eles expressam o processo de compreensão do conhecimento científico e como as ações desenvolvidas pelos professores, na escola e nos espaços não formais, estão contribuindo para ampliar os níveis de alfabetização científica dos estudantes.

Além dos indicadores de Sasseron (2008) é possível utilizar as categorias propostas por Shen (1975), denominadas de Alfabetização prática, cívica e cultural, bem como as categorias de Bybee (1995), quais sejam, alfabetização científica nominal, funcional e processual e multidimensional. A categorização permite avaliar os níveis de alfabetização científica, tanto de materiais didáticos como da aplicação de intervenções no contexto, bem como nos espaços não formais.

$\mathrm{Na}$ atualidade a temática tem sido discutida tanto no espaço escolar como nos espaços não formais, com ênfase, principalmente nos museus, os quais têm se mostrado como potencializadores na promoção da AC.

No contexto educacional a Alfabetização Científica tem sido considerada como uma atividade vitalícia e como um processo permanente. Sua promoção está vinculada a distintas metodologias de ensino, principalmente com o uso de sequências didáticas, organizadas com base nos três momentos pedagógicos, no ensino por investigação, pela pedagogia histórico crítica, entre outras. A utilização de recursos didáticos como filmes, jogos, atividades experimentais, tecnologias de comunicação e informação, teatro, música e outros, estão presentes na organização das sequências didáticas, sempre colocando o aluno como protagonista na construção do conhecimento científico. 
Desta forma, almeja-se que as discussões sobre a Alfabetização Científica e suas contribuições para a formação do educando sejam ampliadas e assumidas pelos sistemas de ensino e que, consequentemente, a AC possa ser incorporada nas ações dos professores que atuam na Educação Básica.

\section{REFERÊNCIAS}

BYBEE, R. W. Achieving scientific literacy. The science teacher, v. 62, n. 7, p. 2833, Arlington: United States, oct. 1995.

CAZELLI, S. Alfabetização científica e os museus interativos de ciência. 1992. Dissertação (Mestrado em Educação) - Pontifícia Universidade Católica, Rio de Janeiro, 1992.

LEAL, M. C.; SELLES, S. E. Sociologia e ensino de ciências: anotações para discussão, In: ENCONTRO NACIONAL DE PESQUISA EM EDUCAÇÃO EM CIÊNCIAS, I, Anais ... Águas de Lindóia: ABRAPEC, 1997. Disponível em:

http://abrapecnet.org.br/atas enpec/ienpec/ienpec.html. Acesso em: 27 out. 2017.

LEAL, M. C.; SOUZA, G. G. Mito, ciência e tecnologia no ensino de ciências: o tempo da escola e do museu. In: ENCONTRO NACIONAL DE PESQUISA EM EDUCAÇÃO EM CIÊNCIAS, I, Anais ... Águas de Lindóia: ABRAPEC, 1997. Disponível em: http://abrapecnet.org.br/atas enpec/ienpec/ienpec.html. Acesso em: 27 out. 2017.

LORENZETTI, L. Alfabetização científicas nas séries inicias. 2000. Dissertação (Mestrado em Educação) - Universidade Federal de Santa Catarina, FlorianópolisSC, 2000.

SASSERON, L. H. Alfabetização científica no ensino fundamental: estrutura e indicadores deste processo em sala de aula. 2008. Tese (Doutorado em Educação) - Universidade de São Paulo, São Paulo, 2008.

SHEN, B. S. P. Science Literacy, American Scientist, v. 63, p. 265-268, may.-jun. 1975.

VIECHENESKI, J. P.; LORENZETTI, L.; CARLETTO, M. R. A alfabetização científica nos anos iniciais: uma análise dos trabalhos apresentados nos ENPECs. In: ENCONTRO NACIONAL DE PESQUISA EM EDUCAÇÃO EM CIÊNCIAS, X, Anais ... Águas de Lindóia: ABRAPEC, 2015.

Recebido: 19 dez. 2016

Aprovado: $19 \mathrm{dez} .2016$

DOI: $10.3895 /$ actio.v2n2.7266

Como citar: LORENZETTI, L. A Alfabetização científica na educação em ciências. ACTIO, Curitiba, v. 2, n.

2, p. 1-3, jul./set. 2017. Disponível em: <https://periodicos.utfpr.edu.br/actio>. Acesso em: XXX.

Correspondência:

Leonir Lorenzetti

Centro Politécnico, caixa postal 19032, Jardim das Américas, Curitiba, Paraná, Brasil.

Direito autoral: Este artigo está licenciado sob os termos da Licença Creative Commons-Atribuição 4.0

Internacional. 